\title{
KONTRIBUSI KARYA TULIS KIAI BASORI ALWI TERHADAP PENGEMBANGAN WAWASAN KEAGAMAAN MASYARAKAT
}

\author{
A6dul Malik Karim Amrullah \\ Fakultas Tarbiyah UIN Maulana Malik Ibrahim Malang \\ Jalan Gajayana No.50 Malang. email: amkamutia@gmail.com \\ Telp. 081233448501
}

\section{Abstrack}

The community is the big institution in the kiai's perception that must be educated base on good values which are suitable for their life. The syari'ah and tasawuf are studied and needed by moslem community, because both of the subject contribute to sove when the moslem community have problem that ussualy happen in the daily of social life. Kiai Basori Alwi is one of kiai's who gives solution to the moslem community with his own manuscript that has been writen when moslem people has problems. Kiai Basori Alwi has a motif to develop student achievement, transform religion knowledge to social community and develop curriculum of pesantren, and keep islamic tradition through his manuscript.

Kiai Basori memiliki pandangan bahwa masyarakat merupakan sebuah institusi besar yang harus dididik dengan nilai-nilai kebenaran. Nilai-nilai kebenaran yang selalu dibutuhkan oleh masyarakat biasanya berorientasi pada kepastian hukum (Syariah) dan ketenangan batin masyarakat (tasawuf). Kiai Basori Alwi merupakan sosok kiai yang selalu memberikan solusi bagi masyarakat dengan manuskrip yang beliau tulis ketika orang-orang Islam memiliki problem terutama yang berkaitan dengan kebutuhan akan kepastian hukum melalui karyanya yang berorientasi pada ilmu syariah serta kebutuhan akan ketenangan batin masyarakat melalui karyanya yang berorientasi pada ilmu tasawuf. Kiai Basori Alwi memiliki motivasi yang sangat tinggi untuk mengembangkan potensi santrinya, mentransformasikan pengetahuan keagamaannya pada kehidupan masyarakat, selain itu juga beliau mengembangkan kurikulum pesantren serta menjaga tradisi Islam melalui karya-karya yang beliau tulis.

Key word: Kiai Basori Alwi, manuscript, contribution, community 


\section{Pendahuluan}

Sejarah telah menjelaskan bagaimana para kiai Basori Alwi berusaha menanamkan nilai-nilai Islam kepada masyarakat. Hal itu biasanya dilakukan oleh para kiai pada saat mereka menjadi "narasumber" baik pada acara-acara hari besar keIslaman maupun acara rutinan yang digelar oleh masyarakat. Selain itu juga masjid atau langgar menjadi media yang sangat efektif bagi kiai untuk untuk mengajarkan ilmu (transfer of knowledge) mereka kepada masyarakat.

Masyarakat bagi diri kiai sebenarnya sebuah "institusi besar" yang harus diberikan materi pelajaran berupa nilai-nilai agung yang cocok bagi mereka. Pelajaran yang sesuai bagi masyarakat adalah persoalan-persoalan furu' iyyah dan tasawuf. Persoalan-persoalan furu'iyyah ditulis oleh kiai berupa persoalan-persoalan yang terjadi dalam kehidupan keseharian masyarakat muslim seperti tata cara tahlil, bagaimana caranya berkurban yang baik dan persoalan-persoalan lainnya.

Sebelum menggelar pengajian biasanya kiai menyusun konsep-konsep berupa ide-ide sesuai dengan tema-tema tertentu yang selaras dengan hari diselenggarakannya pengajian tersebut. Susunan konsep tersebut ditulis oleh kiai dalam satu tulisan. Inilah yang kemudian menjadi tradisi menulis para kiai selama ini.

Kiai Basori Alwi adalah salah satu dari sekian kiai yang mempunyai tradisi seperti itu, akan tetapi kiai Basori Alwi lebih cenderung memiliki kreativitas ketika menyusun tulisan yang akan dipersembahkan kepada masyarakat.

Tulisan ini mencoba untuk mempersembahkan beberapa fakta yang jarang terungkap pada sosok kiai terutama motif kiai Basori Alwi membuat karya tulis dan bagaimana kontribusi karya tulis kiai Basori terhadap pengembangan wawasan keagamaan masyarakat. Beliau merupakan pendiri Pesantren Ilmu al Quran (PIQ) di Singosari, sebuah kecamatan yang ada di wilayah kabupaten Malang.

\section{Biografi Kiai Basori Alwi}

Nama lengkapnya adalah Basori Alwi Murtadlo, dilahirkan di Singosari, 15 April 1927, dari dua pasangan yang bernama Kiai Alwi Murtadlo dan Nyai Riawati. Sejak kecil beliau belajar ilmu al Quran pertama dari ayahnya sendiri, kemudian belajar kepada kakak kandungnya yang bernama kiai Abdul Salam, kemudian dari kiai Yasin Thoyyib (Singosari), kiai Dasuqi (Singosari) kiai Abd. Rosyid (Palembang) ketika beliau masih sekolah Madrasah Aliyah dan mondok di Pondok Pesantren Salafiyah Solo (1946-1949). 
Sebelum belajar di Salafiyah, beliau sudah mondok di Sidogiri dan Legi di Pasuruan sekitar tahun 1940-1943. Selain belajar di pondok-pondok salaf, beliau juga banyak meluangkan waktu untuk belajar Bahasa Arab, belajar pada Ustadz Mahmud al Ayyubi dari Iraq, Sayyid Abd.Rahman bin Syahab al Habsyi (Solo), belajar pada Ustadz Isma'il (Yogyakarta), Ustadz Abd. Nuh (Yogyakarta), kiai Muhammad Yusuf (Surabaya), kiai Ridwan Abdullah (Surabaya), serta Ustadz Sayyid al Idrus (Malang), selain belajar kitab-kitab agama pada mereka, beliau juga banyak belajar ilmu-ilmu umum seperti Bahasa Indonesia dan Bahasa Inggris (Majalah Insan, 2000: 18).

Banyaknya ilmu yang dikuasai oleh beliau membuat beliau banyak dibutuhkan oleh lembaga-lembaga pendidikan baik umum maupun agama, baik formal maupun informal. Mulai tahun 1950 beliau sudah mengajar di SMI Surabaya sampai tahun 1953, pada tahun yang sama juga beliau mengajar di PGA Negeri Surabaya, setelah itu beliau mengajar di PGAA Negeri Surabaya (1953-1958). Pada organisasi non formal, beliau juga banyak berkiprah di GP. Anshor (1955-1958), bahkan pada saat itu beliau ditunjuk menjadi pemimpin oragnisasi itu.

Sekitar tahun 1955 beliau menjadi salah satu pendiri Jam'iyyatul Qurra' Wal Huffadh Jatim sekaligus menjadi salah satu pencetus ide MTQ Nasional dan International di Konfrensi Islam Asia Afrika di Bandung. Setelah lama malang melintang di perantauan, beliau mulai mengabdikan dirinya ke daerah kelahirannya yaitu di Malang, di sana beliau mengajar di PGAA Negeri Malang (1958-1960), juga menjadi dosen Bahasa Arab di IAIN Malang (1960-1961). Pada tahun 1964 beliau menjadi anggota misi kebudayaan Indoensia ke Pakistan, juga menjadi anggota misi ke sebelas negara Islam di Timur Tengah selama 4 bulan.

Menjadi salah satu pencetus ide MTQ Nasional dan Internasional, beliau langsung ditunjuk sebagai dewan hakim dalam MTQ/STQ, baik tingkat propinsi, nasional, dan internasional di Brunei Darussalam (1985), Mesir (1998). Dan akhirnya sekitar tahun 1978 beliau mendirikan pondok pesantren ilmu al Quran hingga sekarang.

\section{Karya-karya Kiai Basori Alwi}

Kiai Basori tergolong sangat produktif, banyak karya-karya yang telah beliau tulis baik dalam bentuk Bahasa Arab ataupun Bahasa Indonesia. Karyakarya itu antara lain:

1. Pelajaran Bahasa Arab seperti Madarij al Durus al Arabiyah 


\section{(I,II,III,IV).}

2. Terjemahan-terjemahan seperti Hukum Islam terjemahan Matan Gayah al Taqrib (I,II), tafsir terjemahan al Quran juz 'Amma (I,II,III), terjemahan Syari'at al Khalidah (karangan DR. Sayyid Alwi al Maliki), Pedoman Tauhid terjemahan Aqidat al Awwam, pengantar Waraqad Imam al Haramain, Membahas Kekuasaan (terjemahan dari al Nasaih al Diniyah wa al Wasaya al Imaniyyah: Buku ini diterjemahkan oleh para santri PIQ dibawah bimbinga kiai Basori Alwi), Memakmurkan Masjid (diterjemahkan dari Tafsir Ayat al Ahkam li al shaikh Muhammad 'Ali al Sabuni: oleh para santri di bawah bimbingan kiai Basori Alwi)

3. Tentang syari'at seperti Dalil-dalil Hukum Islam (I,II,III,IV,V,VI), buku-buku khutbah jum'at (4 judul), al Miqat al Jawi li Hajji Indonesia (Miqot Udara bagi Haji Indonesia), Petunjuk Singkat Tentang Qurban, Petunjuk Singkat manasik Haji, Empat Sumber Hukum Islam Quran-Sunah-Ijma'-Qiyas.

4. Ilmu-ilmu al Quran seperti Pokok-pokok Ilmu Tajwid dan Kamus Waqaf serta Ibtida', al Gharaib fi al Rasm al Uthmani, Ahadits fi Fadail al Quranwa qurraihi (Beberapa hadits tentang keutamaan al Quran dan para pembacanya.

5. Ilmu-ilmu Aqidah seperti Pokok-pokok Ahlussunnah wal jama'ah, Perbandingan Ahlisunnah waljamaah, Pengantar Ilmu Ahl al Sunnah wa al Jaama'ah (Untuk Madrasah Tsanawiyah/Sekolah Lanjutan), Sikap Golongan-golongan Islam terhadap Sahabat (Mu'tazilah, Syi'ah, Khawarij, Ahlisunnah waljamaah), Fatwa Shaikh Muhammad 'Ali al Maliki “al Sadaqah wa al Tahlil 'an al Mayit wa Surah Yasin" Aqidat alAwwam.

\section{Motif dan Kontribusi Karya Tulis Kiai Basori Alwi dalam}

\section{Pengembangan Keilmuwan Santri melalui Tradisi Menterjemahkan}

Kebiasaan menterjemahkan kitab-kitab terdahulu merupakan tradisi para kiai, namun tidak banyak yang mempublikasikan karya terjemahannya tersebut untuk konsumsi masyarakat maupun santrinya. Kiai Basori berusaha mengembangkan wacana intelektual para santrinya untuk menerjemahkan kitabkitab yang nantinya akan dipakai sebagai konsumsi masyarakat secara umum, seperti kitab al Nasaih al Diniyyah wa al Wasayah al Imaniyyah yang membahas tentang "Kekuasaan", juga kitab Imarat al Masajid yang diterjemahkan dari Tafsir Ayat al Ahkam karya Syekh Ali al Sabuni. Dalam mukadimah kitab itu ditulis sebagai berikut: 
Terjemahan ini adalah hasil karya para santri dari pengajian rutin yang diberikan pengasuh dengan metode Cara Belajar Siswa Aktif.

Di samping didiskusikan dengan latihan berbahasa Arab juga ditugaskan kepada masing-masing kelompok untuk menerjemahkannya sebagai sumbangan PIQ kepada masyarakat.

Karya tulis tersebut merupakan karya hasil terjemahan para santri hasil belajar dengan model nyarahi yaitu model sorogan yang didahului oleh kiai yang membaca setelah para santri menuliskan hasil terjemahan tersebut pada sela-sela tulisan arab pego (kitab tanpa harakat). Tulisan tersebut beliau terbitkan sendiri secara internal untuk kepentingan pengembangan kemampuan para santri. Selain untuk pengembangan kemampuan santri hasil terjemahan tersebut juga digunakan oleh kiai Basori Alwi untuk memberikan wawasan kepada masyarakat.

Jadi jelaslah bahwa kecenderungan dari Kiai Basori Alwi untuk mengembangkan intelektual para santrinya dengan memperhatikan pada permasalahan masyarakat yang sebenarnya membutuhkan banyak informasi tentang ilmu-ilmu syari'at Islam secara mendalam. Selain ilmu-ilmu syari'at juga kiai Basori Alwi menerjemahkan buku-buku tasawuf yang muatannya kemungkinan itba' pada guru tarikat beliau yang bernama H. Muhammad Uthman Nadi al Ishaqi. Kitabnya yang merupakan terjemahan dari karya gurunya itu berisikan tentang tata cara berdhikir al Qalbi bi Ismi al Dzati au bi al Nafyi wa al Ithbat Inda al Taifah al Naqshabandiyah al Ahmadiyah. Salah satu Ciri khas dzikir tarekat naqshabandiyah adalah nafi ithbat, wuquf qalbi yang mengajarkan tata cara berdzikir ittisal dengan Allah.

Kiai Basori dikenal sebagai badal dari kiai Uthman Nadi al Ishaqi pengasuh pondok pesantren Dar al Ubudiyah Raudat al Muta'allimin, Jatiporo Surabaya. Salah satu temannya mengatakan:

Dulu Basori Alwi dikenal sebagai badal dari kiai Uthman, beliau hanya memberangkatkan murid-murid yang ingin mendalami tariqat, selain itu beliau juga memberi wejangan-wejangan pada murid-murid yang akan berangkat itu (Amrullah, 2003: 23).

Karena pengaruh inilah mungkin yang menyebabkan Basori tidak banyak melakukan kritik-kritik pedas yang beliau tuangkan di beberapa karya tulis yang dipublikasikan pada sang guru yang dianggap mulya oleh beliau atau bisa jadi pada teman-teman beliau yang dianggap satu aliran yaitu Sunni. Jadi kebanyakan karya Kiai Basori Alwi yang dipublikasikan adalah terjemahan- 
terjemahan dari kitab-kitab fiqih dan tasawuf.

Menurut Martin van Bruinessen ada perbedaan besar antara karya ulama modern dan reformis dengan karya ulama tradisional. Ulama modern menulis karyanya dalam Bahasa Indonesia dengan huruf latin (kalangan reformis membaca karya-karya ulama Arab biasanya melalui terjemahan Bahasa Indonesianya). Sementara ulama tradisional menulisnya dengan Bahasa Arab, karena dianggap menambah nilai kehormatannya. Kalaupun karya mereka ditulis dalam bahasa setempat ( $a r a b$ pego), namun tetap memakai huruf Arab (Bruinesen, 2000: 78). Kiai Basori Alwi adalah sosok keduanya, dimana beliau juga sering menulis karyanya dalam Bahasa Latin dan banyak juga yang menulis dalam Bahasa Arab.

\section{Transformasi Ilmu Keagamaan pada Masyarakat Melalui Karya Tulis}

Persyaratan bagi semua fungsi kependidikan dan kemasyarakatan lainnya dari seorang kiai adalah peranannya sebagai ahli tentang Islam. Begitu juga pimpinan pesantren dinamakan "alim", jika dia berpendidikan pesantren, mampu membaca kitab kuning, menafsirkan dan mengajarkan al Quran dan naskah-naskah keagamaan serta ulasan yang terpenting di dalam Bahasa Arab. Selanjutnya Kiai berfungsi sebagai seorang ulama, artinya ia menguasai pengetahuan dalam tata masyarakat Islam dan menafsirkan peraturan-peraturan dalam hukum agama. Dengan demikian ia mampu untuk memberikan nasehat, melerai, dan menentukan sedalam seorang ahli hukum di pedesaan sekitar pesantren itu. Di dalam upacara-upacara keislaman ia adalah seorang khatib dan Imam serta berwenang untuk menafsirkan dan menjaga aturan-aturan dan pandangan agama.

Dibanding dengan ahli (akademis) Islam (alim, ulama), maka kiai lebih memerlukan pengetahuan praktis di masyarakatnya serta daya penafsiran dalam rangka kegiatannya di desa tempat ia bertugas. Dari segi fungsi, sosok ulama pada masyarakat Jawa terbagi ke dalam dua kelompok. Kelompok pertama ialah kelompok ulama bebas atau ulama yang kedudukan peran sosialnya berada di jalur al Da'wah wa al Tarbiyah. Ulama kelompok ini biasanya disebut juga sebagai kiai pesantren atau ulama pondok pesantren, dengan tugas utamanya sebagai guru dan pengajar sekaligus penyiar (muballigh) agama (Ismail, 1997: 54).

Pekerjaan ini tidak lain merupakan usaha untuk memahamkan Islam kepada masyarakat. Kiai pondok pesantren ini hidupnya menetap di pedesaanpedesaan. Melalui kegiatan pendidikan dan penyiaran agama, mereka 
membangun masyarakat desa-desa di Jawa, sehingga pedesaan-pedesaan Jawa di jumpai tumbuhnya sistem sosial yang struktur dan kultur sosialnya bercorak keIslaman. Kelompok yang kedua adalah kelompok ulama pejabat atau disebut dengan panggilan penghulu. Kelompok ulama ini peran sosial keagamaannya berada di jalur al Tasyri' wa al Qada, yakni aktivitas sosial keagamaan yang menonjol sebagai pelaksana bidang kehakiman yang menyangkut hukum (syariat) Islam (Ismail, 1997: 109).

Keahlian para kiai seperti itu tampaknya menjadikan mereka lebih dipercaya oleh masyarakat, bahkan masyarakatpun banyak yang berduyunduyun untuk mendatangi para kiai itu untuk dimintai nasehat dan doa. Peran seperti itu sangatlah diperlukan oleh seorang kiai karena mereka merupakan bahan rujukan bagi masyarakat awam. Bidang kajian yang digeluti oleh seorang kiai memang terkadang berbeda-beda kadang ada yang ahli ilmu hadith yang terkenal dengan sebutan Muhadithin, ada yang ahli ilmu al Quran, mereka disebut qura', ada juga yang menyebut mufassirin, ahli di bidang fiqih yang disebut sebagai fuqaha dan lain sebagainya.

Masyarakat bagi diri kiai sebenarnya sebuah "institusi besar" yang harus diberikan materi pelajaran yang cocok bagi masyarakat. Pelajaran yang sesuai bagi masyarakat adalah persoalan-persoalan furu'iyyah dan tasawuf. Persoalanpersoalan furu'iyyah ditulis oleh kiai berupa persoalan-persoalan yang terjadi dalam kehidupan keseharian masyarakat muslim seperti tata cara tahlil, bagaimana caranya berkurban yang baik dan persoalan-persoalan lainnya.

Ada dua tahapan bagaimana kiai mengajarkan materi pelajarannya kepada masyarakat yang pertama, mereka mengutus para santrinya untuk mengajarkan sebuah materi kepada masyarakat, misalnya Kiai Basori seringkali mengutus para santrinya untuk mengajar di Panti Asuhan Darussalam Singosari, materimateri yang diajarkan biasanya kitab-kitab yang sudah mashur. Yang kedua kiai sendiri yang turun tangan mengajar materi pelajarannya kepada masyarakat, materi pelajarannya terkadang tulisan kiai sendiri yang berisi rangkuman dari kitab-kitab terdahulu, biasanya berisi tentang cara-cara praktis orang-orang Islam dalam beribadah, misalnya karya Kiai Basori tentang Miqot Udara Haji Indonesia, al Sadaqah wa al Tahlil, Dalil-Dalil Hukum Islam I (bersesuci), Dalil-Dalil Hukum Islam (Shalat) dan lain-lain.

Selain itu materi-materi pelajaran yang diajarkan oleh kiai adalah tasawuf (moral). Materi tasawuf seringkali diaplikasikan dengan kegiatan-kegiatan tarekat, istighathah, dan tampaknya dua materi inilah yang lebih digandrungi masyarakat, hal ini sangat wajar karena secara filosofi materi tasawuf sebenarnya 
menunjukkan kasih sayang Tuhan (rahman-rahim Allah). Sedangkan materi fiqh disenangi karena masyarakat bisa memperbaiki ibadahnya secara benar. Secara garis besar model pengajaran kiai pada masyarakat digambarkan sebagai berikut:

Model pertama:

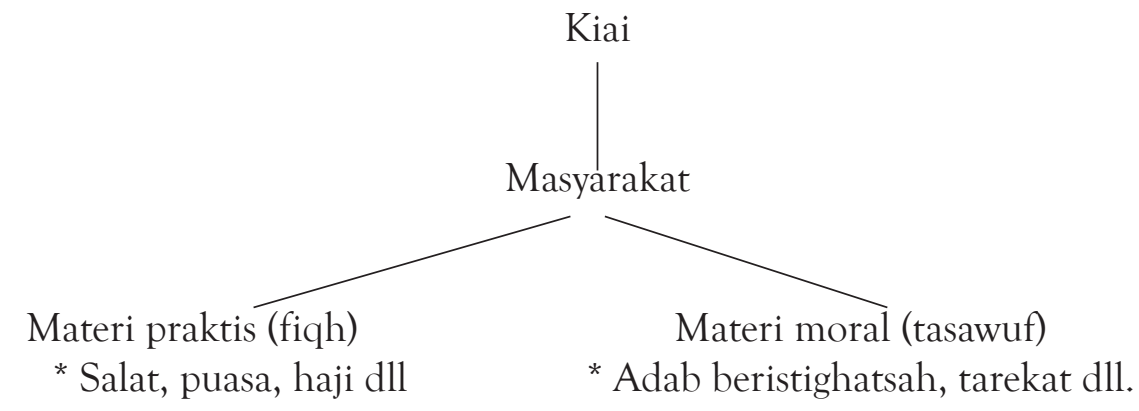

Gambar 1. Bagan model pertama pengajaran kiai pada masyarakat

Model kedua:

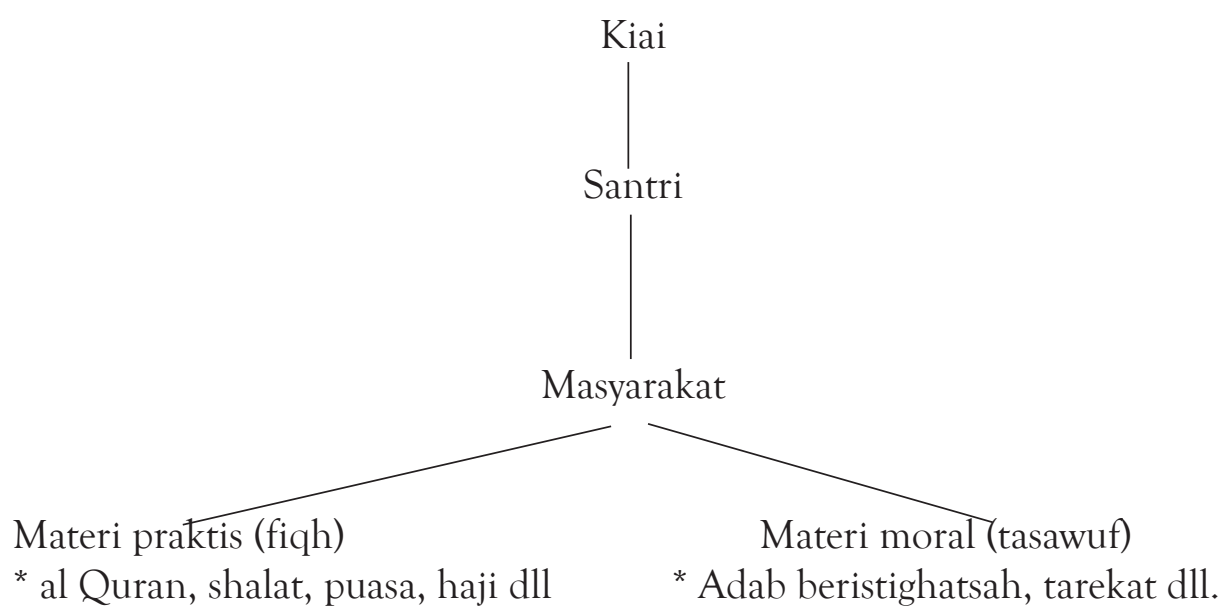

Gambar 2. Bagan model kedua pengajaran kiai pada masyarakat

Kiai Basori banyak memberikan qias jika ada permasalahan umat, bisa dilihat dalam kitabnya yang berjudul Hukum al Talqin wa al Tahlil li Amwat al 
Mu'minin (Hukum Talqin dan Tahlil untuk Mayat Orang-Orang Mu'min), al Miqat al Jawwi li Hujaj Indonesiya (Miqat Udara Haji Indonesia). Permasalahan umat Islam semacam ini, tergolong baru bagi kiai karena fenomena seperti ini merupakan tradisi sebuah masyarakat yang belum didapati pada masa Nabi Muhammad SAW. Dalam karyanya itu Kiai Basori Alwi menuturkan tentang hukum-hukum tahlilan:

Tradisi di lingkungan Ahlussunnah wal Jama'ah di dunia di antaranya di Indonesia, orang secara kolektif membaca al Quran, tahlil dan tasbih, shalawat dan do'a kemudian berselamatan atau bersedekah untuk jenazah yang telah dikebumikan. Semua ini disingkat namanya tahlil, hukumnya adalah sunnat. Dasarnya adalah hadits-hadits dibawah ini "Dari Aisyah R.A, bahwa seorang laki-laki datang kepada Nabi Muhammad, lantas berkata "Wahai Rasulullah, sesungguhnya ibuku telah meninggal dunia dengan mendadak sedang ia tidak berwasiat, dan aku kira ia andaikan berkata ia menyuruh bersedekah, apakah ia memperoleh pahala jika aku bersedekah untuknya?" Nabipun bersabda "Ya" (Bukhari, Muslim, Nasa'i) (Alwi, 1998: 89).

Dari kata pengantarnyapun Kiai Basori Alwi berkomentar:

Makalah ini disajikan untuk memenuhi permintaan rekan-rekan Ahlisunnah wal Jama'ah yang selalu mengamalkan tahlil dan selamatan untuk mayat-mayat kaum mu'minin. Amalan ini telah membudaya khususnya di Indonesia. Mereka ingin mengetahui dasar shara' bagi amalan tersebut (Alwi, 1998:1).

Dari kitab ini juga Kiai Basori Alwi membuat rumusan pertanyaan seputar tahlil, beserta qiyasnya:

Pertanyaan; Apakah pelaksanaan tahlil dan menyelamati mayat yang terjadi/ yang dilakukan orang sekarang adalah sama dengan tahlil dan sedekah untuk mayat pada zaman Nabi?

Jawaban: Andaikan sama tidaklah dipermasalahkan lagi, andaikata tidak sama, itu adalah soal tehnik. Memang Nabi tidak menentukan secara khusus tehnik pelaksanaan tahlil dan selamatan untuk mayat itu. Yang penting asalkan tidak bertentangan dengan pokok-pokok shari'at. Hal itu sama dengan kewajiban menuntut ilmu, baik yang fardu ain maupun yang fardu kifayah. Tehnik belajar dan mengajar yang dilakukan Nabi dan sahabatnya tidaklah seperti apa yang terjadi dan berkembang pada zaman ini (Alwi, 1998; 15).

Jadi jelaslah, bahwa keyakinan diri seorang kiai terhadap permasalahan umat masa kini, bisa diqiyaskan pada keadaan-keadaan jaman Nabi Muhammad SAW. Dan tampaknya, karya-karya semacam inilah yang menjadi karakter 
khusus para kiai, terutama kiai tradisional. Bagaimanapun juga, ketika karya mereka dipandang tidak mampu menyelesaikan permasalahan-permasalahan umat Islam, namun semua tuduhan itu masih harus diperdebatkan lagi pada sebatas apa permasalahan umat Islam sekarang, jika memang masih bisa diqiyaskan pada hadits-hadits Nabi Muhammad SAW.

\section{Karya Tulis Kiai debagai Bahan Kajian di Pesantren dan Sekolah}

Kurikulum pesantren sebenarnya berupa materi-materi keagamaan yang biasa disebut sebagai kitab kuning. Kitab kuning ini merupakan kitab karya para ulama terdahulu yang berisikan ajaran-ajaran syari'ah seperti fiqih, tasawuf sebagai Ihya' Ulumudin, tata bahasa seperti Nahwu Jurumiyah (al Jurmiyyah), Alfiyah dan lain sebagainya.

Karya-karya yang telah ditulis oleh Kiai Basori serta kiai-kiai yang lainnya, telah membuktikan dinamisnya dunia pesantren. Bahkan dalam sistem pesantrenpun karya mereka telah mewarnai kurikulum pesantren yang selama ini didominasi oleh kitab-kitab klasik ulama-ulama dahulu atau yang lebih dikenal dengan sebutan kitab kuning. Beberapa karya tulis kiai Basori Alwi seperti; Pokok-Pokok Ilmu Tajwid, Kamus Waqaf dan Ibtida', Ahadith fi Fadail al Quranwaqurratihi, Madarij al Durus al Arabiyyah (jilid I, II, III, IV) diajarkan pada pesantren PIQ. Kedua karyanya itu sekarang menjadi spesialisasi PIQ yang terkenal dengan ilmu al Quran dan bahasa Arabnya. Karena karyanya itu, semakin menjadikan materi pelajaran di dunia pesantren semakin berkembang. Selain itu juga sempat karya Kiai Basori Alwi ini mewarnai kurikulum Madrasah Ibtida'iyah (setingkat SD) sekitar tahun 1980-an (Amrullah, 2003: 89).

\section{Memurnikan Ajaran Islam Lewat Karya Tulis}

Kiai Basori yang dikenal sebagai figur pemimpin yang banyak menghasilkan karya tulis mempunyai motivasi atau perencanaan dalam membentuk karakter para santrinya ditujukan untuk masyarakat pada umumnya dan para santri khususnya, buku-buku karya beliau tersebut secara tidak langsung membentuk karakter khas santri PIQ dalam mensikapi masalah mereka lebih cenderung sangat hati-hati ketika ada sebuah masalah yang dilontarkan oleh kelompok tertentu atau figur tertentu. Dalam buku-bukunya yang berjudul; Perbandingan Aqidah 95 Ahlisunnah Waljamaah, Pengantar Ilmu Ahlisunnah Waljamaah, Pokok-Pokok Aqidah Ahlussunnah wal jamah, Sikap Golongan-Golongan Islam Terhadap Sahabat (Mu'tazilah, Syi'ah, Khowarij, Ahlissunnah Waljamaah) serta Ahlussunnah-Syiah dan Bermadzhab. Kitab-kitab yang ditulis oleh Kiai Basori 
Alwi ini banyak meruju' pada aktivitas golongan-golongan yang beliau yakini benar yaitu Ahlussunnah dengan golongan-golongan yang beliau salah seperti Syi'ah, Khawarij, dan Mu'tazilah. Tulisan-tulisan itu menjadi lebih ditekankan ketika Abdurrahman Wahid mengatakan bahwa tradisi NU merupakan Syi'ah kultural. Pendapat Kiai Abdurahman Wahid ini tampaknya dianggap menjadi sumber polemik bagi keyakinan Ahlussunnah wal Jama'ah. Dalam suatu dialog dengan para santrinya kiai Basori ditanya:

"Syi'ah adalah kaum muslimin, mengapa kita begitu bermusuhan dengan orang Islam sendiri?"

Kiai Basori menjawab: "Syi'ah yang dibawa oleh Imam Khomeini adalah Syi'ah Ghulat yang harus diperangi, maka menyelamatkan satu orang Islam lebih baik daripada memasukkan orang kafir pada Islam" (Amrullah, 2003: 70).

Dalam majalah-majalah yang diterbitkan oleh PIQ, kiai Basori banyak mengomentari tentang gerakan syi'ah ini:

Dampak dari ajaran filsafat-filsafat dan pengikut Islam yang berasal dari agama Yahudi, Kristen, Majusi dan lain-lain menimbulkan pemikiran-pemikiran baru dalam Islam, maka muncullah beberapa golongan yang menyimpang dari ajaran Islam. Ditengah-tengah kekacauan berfikir ini dan ditengah-tengah aliran yang diciptakan masing-masing golongan, tampillah segolongan orangorang yang ikhlas meluruskan aqoid kaum muslimin diatas garis dan cara al Quran. Mereka menamakan Ahlus-Sunnah wal Jama'ah, golongan yang jauh sebelumnya disebut-sebut oleh Nabi Muhammad SAW, dan kini pengikutnya mencapai 95 persen seluruh dunia (Alwi, 1994: 11).

Kiai Basori berkeyakinan bahwa ajaran-ajaran atau doktrin-doktrin yang dibawa oleh Shi' ah adalah salah. Konteks eksternal seperti inilah mengakibatkan Kiai Basori menulis. Jadi aliran Shi'ah sebenarnya sebuah ancaman serius. Hal itu bisa dilihat dalam mukadimah dari kitab "Ahlusunnah wal Jama'ah Shi'ah dan Berjamaah, beliau mengatakan:

Sampai saat ini masih banyak masyarakat Islam terutama generasi muda yang belum mengenal lebih jauh tentang Syi'ah, terutama dalam segi aqidah dan perbedaannya yang mendasar dengan Ahlusunnah wal Jama'ah. Mereka mengenal Syi'ah hanya dari sisi lain yang mereka anggap pas dengan kondisi mereka (Alwi, 1996: 71).

Namun, perlu diketahui bahwa Kiai Basori banyak memperoleh pelajaran dari para habib (istilah untuk sebutan keturunan Nabi Muhammad) seperti gurunya Sayid Alwi al Idrus, Sayyid Muhammad bin Alwi al Maliki yang 
keduanya adalah Muhadithin beraliran Sunni, kemungkinan besar dari para guru-gurunya inilah Kiai Basori Alwi terpengaruh pada gaya berifikir habaib tersebut yaitu gaya berfikir yang cenderung puritan. Hal tersebut dilakukan karena memang dibutuhkan oleh masyarakat di tengah ombang-ambing ketidakpastian hukum akibat terjadi berbagai penafsiran yang beragam sehingga berdampak pada kebingungan masyarakat.

Hal ini bisa diwajari karena memang sejak dahulu antara Sunni dan aliran-aliran lainnya terutama Syi'ah sudah berbenturan antara keduanya. Lebih-lebih ketika Islam masuk ke Indonesia, tampaknya benturan antara dua aliran ini yang pada awalnya merupakan perdebatan intelektual, menjadi benturan yang mengarah pada fisik.

Dalam kitabnya kiai Basori Alwi mengatakan:

"Yang mulia Assayyid Muhammad bin Alwi yang banyak karangannya, diantaranya kitab Syari'atullah al Khalidah sebuah kitab yang bermutu tinggi untuk studi sejarah Perundangan Hukum Islam dan Madhhab-Madhhab Fuqaha (Ahli-Ahli Hukum Islam) yang kenamaan, beliau pernah berkata kepada al Faqir: "Saya sangat bergembira, kalau saudara sudi menterjemahkan sebuah saja dari kitab-kitab karangan saya".

Alhamdulillah, dengan takdir dan pertolongan Allah, akhirnya alfaqir berkesempatan menterjemahkan dan meringkas beberapa bab dari kita beliau diatas dengan membacanya, insyaallah akan makin diketahuilah, betapa besar jasa para ulama dahulu kala dalam menjabarkan Hukum-Hukum Islam (Fiqh) sehingga menjadi pedoman umat Islam di seluruh dunia dari abad-ke abad dalam melaksanakan agama mereka (al Maliki, $1404 \mathrm{H}$ ).

Ungkapan diatas menunjukkan bahwa kiai Basori Alwi, cenderung terpengaruh dengan sayyid Muhammad bin Alwi al Maliki. Hal ini sebenarnya bisa dikatakan bahwa polemik berkepanjangan antara dua golongan utama dalam Islam yaitu Sunni dan Syi'ah masih berlanjut. Usaha untuk memurnikan syari'at Islam bagi Kiai Basori Alwi juga tampaknya menjadi landasan beliau untuk menulis sebuah buku pegangan bagi masyarakat awam.

Kiai Basori sendiri dalam hal ini juga melihat kebutuhan masyarakat untuk mempelajari Islam dengan benar sesuai dengan tuntunan shari'ah Islam. Perlu diketahui bahwa perdebatan-perdebatan yang dilakukan oleh dua ormas terbesar yaitu NU dengan Muhammadiyah tentang hukum-hukum yang bersifat furu'iyyah telah begitu meresahkan masyarakat, seperti perdebatan tentang hukum tahlilan, hukum membaca doa qunut dan lain sebagainya. Hal inilah yang kemungkinan besar menyebabkan Kiai Basori Alwi menulis 
buku-buku sebagai pedoman masyarakat agar bisa menenangkan hati mereka. Karya-karyanya yang berkenaan dengan pemurnian shari'ah adalah: Hukum Talqin dan Tahlil Untuk Mayat Orang-Orang Mukmin, Sadaqah dan Tahlil. Hipotesa seperti di atas bisa dibuktikan pada muqadimah kitab yang beliau tulis:

"Makalah ini disajikan untuk memenuhi permintaan rekan-rekan Ahlissunnah wal jama'ah yang selalu mengamalkan tahlil dan selamatan untuk mayat-mayat kaum mukminin. Amalan ini telah membudaya khususnya di Indonesia. Mereka ingin mengetahui dasar syari'at bagi amalan tersebut" (Alwi, 1997: 86).

\section{Simpulan}

Dari uraian di atas dapat diambil kesimpulan bahwa kiai mempunyai tradisi menulis dengan beberapa motif. Motif yang pertama adalah pengembangan keilmuwan santri yaitu dengan menterjemahkan beberapa kitab yang dianggap penting untuk masyarakat. Terjemahan tersebut akhirnya dipublikasikan sebagai bahan ajar untuk masyarakat. Motif yang kedua adalah transformasi ilmu-ilmu agama kepada masyarakat terutama ilmu-ilmu dasar yang biasa diperbincangkan oleh masyarakat seperti pengenalan haji, tahlilan. Model pengajaran yang biasanya dilakukan oleh kiai ada dua macam yang pertama model pengajaran langsung kiai ke masyarakat yang kedua adalah pendelegasian kiai pada ustad yang mengajar ke masyarakat.

Motif yang ketiga adalah menjadikan karya tulis kiai sebagai bahan kajian pada pengembangan kurikulum pesantren, sehingga hampir semua karya tulis kiai Basori diajarkan mulai dari kelas dasar sampai menengah untuk penguasaan kompetensi al Quran dan Bahasa Arab. Motif yang keempat adalah memurnikan ajaran-ajaran Islam yang dianggap melenceng oleh kiai dan harus segera untuk diluruskan demi menjaga ajaran-ajaran Islam di masyarakat. Beberapa motif di atas ini yang menjadikan Kiai Basori Alwi menjadi seorang penulis yang produktif dan memiliki kontribusi yang sangat penting bagi pengembangan wawasan masyarakat tentang ajaran-ajaran Islam terutama pada wawasan materi figh dan tasawuf yang selama ini menjadi problem keseharian masyarakat setempat terutama pada kepastian hukum yang selama ini dijadikan pegangan oleh masyarakat. Karya tulis kiai juga mewarnai pengembangan kurikulum baik kurikulum pesantren maupun sekolah atau madrasah ibtidaiyah 


\section{Daftar Pustaka}

al Maliki, M. b. A. 1404 H. Syari'atullah al Khalidah (B. Alwi, Trans.). Singosari, Jawa Timur, Indonesia: PIQ.

Alwi, B. 1994. Syi'ah. Majalah Insan. Singosari: PIQ.

Alwi, B. 1996. Ahlu Sunnah wal Jama'ah dan Berjama'ah. Singosari, Jawa Timur, Indonesia: PIQ.

Alwi, B. 1997. Hukum Talqin dan Tahlil Untuk Mayat Orang-Orang Mukmin. Singosari: PIQ.

Alwi, B. 1998. Hukum Tahlil dan Tahlil Untuk Mayat Orang-Orang Mukmin. Singosari, Jawa Timur, Indonesia: PIQ.

Amrullah, A. M. K. 2003. Kiai dan Tradisi Menulis. Surabaya: IAIN Sunan Ampel.

Dhofier, Zamakhsari. 1994. Tradisi Pesantren, studi tentang pandangan hidup kiai Jogjakarta: LP3ES.

Ismail, I. Q. 1997. Kiai Penghulu Jawa; Peranannya di Masa Kolonial. Jakarta: Gema Insani Pers.

Majalah Insan, Gema Santri Untuk Umat, edisi XIII/6/. (Singosari: PIQ, 2000).

Van Bruinesen, M. 2000. Kitab Kuning, Pesantren dan Tarekat. Jakarta: Mizan.

Ziemek. Manfred. 1983. Pesantren Dalam Perubahan Sosial. Jakarta: Perhimpunan Pengembangan Pesantren dan Masyarakat. 